\title{
Effect of Sintering Temperature on the Properties of Aluminium- Aluminium Oxide Composite Materials
}

\author{
Dewan Muhammad Nuruzzaman, Farah Fazira Binti Kamaruzaman, and Nasrah Binti Mohd \\ Azmi
}

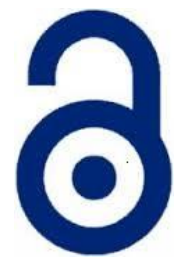

\author{
Received: 06 October 2016 \\ Accepted: 07 December 2016 \\ Published: 20 December 2016 \\ Publisher: Deer Hill Publications \\ (c) 2016 The Author(s) \\ Creative Commons: CC BY 4.0
}

\begin{abstract}
In this study, aluminium-aluminium oxide $\left(\mathrm{Al}-\mathrm{Al}_{2} \mathrm{O}_{3}\right)$ metal matrix composites of different weight percentage reinforcements of aluminium oxide were processed at different sintering temperatures. In order to prepare these composite specimens, conventional powder metallurgy (PM) method was used. Three types specimens of different compositions such as $95 \% \mathrm{Al}+5 \% \mathrm{Al}_{2} \mathrm{O}_{3}, 90 \% \mathrm{Al}+10 \% \mathrm{Al}_{2} \mathrm{O}_{3}$ and $85 \% \mathrm{Al}+15 \% \mathrm{Al}_{2} \mathrm{O}_{3}$ were prepared under 20 ton compaction load. Then, all the specimens were sintered in a furnace at two different temperatures $550^{\circ} \mathrm{C}$ and $580^{\circ} \mathrm{C}$. In each sintering process, two different heating cycles were used. After the sintering process, it was observed that undistorted flat specimens were successfully prepared for all the compositions. The effects of sintering temperature and weight fraction of aluminium oxide particulates on the density, hardness and microstructure of $\mathrm{Al}_{-}-\mathrm{Al}_{2} \mathrm{O}_{3}$ composites were observed. It was found that density and hardness of the composite specimens were significantly influenced by sintering temperature and percentage aluminium oxide reinforcement. Furthermore, optical microscopy revealed that almost uniform distribution of aluminium oxide reinforcement within the aluminium matrix was achieved.
\end{abstract}

Keywords: Aluminium-Aluminium Oxide, Metal Matrix Composite, Density, Hardness, Microstructure

\section{INTRODUCTION}

In recent years, particle reinforced metal matrix composites (MMCs) are gaining popularity for advanced applications. Generally, in processing of a metal matrix composite, a soft metal with high ductility and toughness is reinforced by a hard ceramic material with high strength and modulus. These metal-ceramic composites are capable of multiple functions in diverse engineering fields. For structural applications, aluminium based metal matrix composites have significant potential due to their high stiffness, modulus, specific strength, corrosion and wear resistance. In the development of these MMCs, substantial progress has been achieved so that these composites can be used for potential applications such as in automotive and aerospace industries. Researchers reported that these metal matrix composites are suitable for high performance structures and showed improved properties over conventional metals and alloys [1-4].

Friction and wear behaviors of $\mathrm{A} 359-20$ vol\% $\mathrm{SiC}$ particle composites slid against automobile friction material were experimentally investigated [5]. It was found that the wear resistance of the composites was greatly related to the strength and hardness of the $\mathrm{SiC}$ particles. Fatigue lives of aluminium alloy-alumina silicate particulate composites were investigated [6] and it was found that these composites showed longer fatigue lives in lower stress state than the unreinforced aluminium alloy whereas at elevated stress state, these composites exhibited reduced fatigue lives regardless of the reinforcement fractions. The properties of MMCs depend on many factors such as different properties of matrix material, size, shape, hardness, volume fraction and distribution of the reinforcement etc. [7]. Thermal conductivity and microstructure of the aluminium oxide particulate reinforced aluminium composites were investigated [8]. The obtained results revealed that the thermal conductivity of the composites was significantly influenced by the volume fraction of aluminium oxide. Mechanical properties of silicon carbide particulate dispersed composites were investigated [9] and it was found that due to the addition of silicon carbide particulates, hardness and sliding wear resistance properties were improved. Microstructure and properties of zinc oxide whiskers reinforced aluminium based composites were investigated [10]. The obtained results revealed that composite properties were

D. M. Nuruzzaman 凶, F. F. B. Kamaruzaman, and N. B. M. Azmi

Faculty of Manufacturing Engineering, University Malaysia Pahang

26600 Pekan, Pahang Darul Makmur, Malaysia

E-mail: dewan052005@yahoo.com

Reference: Nuruzzaman, D. M., Kamaruzaman, F. F. B. and Azmi, N. B. M. (2016). Effect of Sintering Temperature on the Properties of Aluminium-Aluminium Oxide Composite Materials. International Journal of Engineering Materials and Manufacture, 1(2), 59-64 
greatly influenced by the reinforced zinc oxide. The influence of different weight fractions of silicon carbide particulate reinforcement on the properties of aluminium based metal matrix composites were investigated [11]. The obtained results revealed that hardness and impact strength of the composites were significantly influenced by the weight fraction of silicon carbide.

In this study, aluminium was used as matrix material and aluminium oxide was used as reinforced material for the preparation of MMC. In the fabrication, aluminium-aluminium oxide composite specimens containing 5\%, 10\% and $15 \%$ weight percentages of aluminium oxide particulates were prepared under 20 ton compaction load. After that, all the specimens were sintered at two different sintering temperatures $550^{\circ} \mathrm{C}$ and $580^{\circ} \mathrm{C}$ using two heating cycles. The effects of sintering temperature and weight fraction of aluminium oxide particulates on the properties of $\mathrm{Al}-\mathrm{Al}_{2} \mathrm{O}_{3}$ composites were investigated. The properties such as hardness, density and microstructure of the composites were analyzed.

\section{EXPERIMENTAL}

In processing of the aluminium-aluminium oxide $\left(\mathrm{Al}-\mathrm{Al}_{2} \mathrm{O}_{3}\right)$ composite specimens, conventional powder metallurgy (PM) method was used. For the processing of composites, aluminium powders were used as matrix material and aluminium oxide particulates were used as reinforcement. In the fabrication process, 5\%, 10\% and $15 \%$ weight fractions of aluminium oxide powder materials were added to $95 \%, 90 \%$ and $85 \%$ weight fractions of aluminium powder respectively to prepare three types of composite specimens. In order to process the specimens, the major three steps are blending, compacting and sintering. At the beginning, on the basis of molecular weight, the weights of aluminium and aluminium oxide powders were measured. In order to achieve a good homogeneous mixture, mixing and blending of metal and ceramic powders were carried out so that ceramic $\mathrm{Al}_{2} \mathrm{O}_{3}$ particulates are uniformly distributed into the aluminium matrix. A cylindrical steel die was used for the cold compaction of mixed $\mathrm{Al}_{-}-\mathrm{Al}_{2} \mathrm{O}_{3}$ powders of different compositions. The mixed powders were cold compacted at room temperature using a hydraulic press (TOYO: Model TL30, capacity 30 Ton). All the composite specimens were prepared under 20 ton compaction load. At this stage, these green compacts are very fragile and the cohesive strengths of these green compacts are very low. After that, these green compact specimens were sintered using a sintering furnace (Nabertherm: Made in Germany). Two heating cycles were applied during the sintering process. In the first cycle, the temperature started from about $30^{\circ} \mathrm{C}$ and with a heating rate of $5^{\circ} \mathrm{C} / \mathrm{min}$, it reached to $400^{\circ} \mathrm{C}$. At this temperature, a holding time of 30 minutes was maintained. During the second cycle, with a heating rate of $5 \circ \mathrm{C} / \mathrm{min}$, the temperature started from $400^{\circ} \mathrm{C}$ which reached to sintering temperature $550^{\circ} \mathrm{C}$ and a holding time of 1 hour 30 minutes was maintained. At the last stage of sintering, the specimens were allowed to cool in the furnace in order to reach the room temperature. Same processes were followed for another set of specimens of different compositions and all the specimens were sintered at a different temperature $580^{\circ} \mathrm{C}$. After completing the sintering process, all the samples were prepared for characterization and hardness testing. Using a metallurgical microscope (OLYMPUS BX51M, Made in Japan), microstructural analyses of the samples were carried out. Vickers hardness measurements of the samples were carried out using microvickers hardness tester (Wilson Hardness: Model 402 MVD, Made in USA). For the microvickers hardness measurement of the specimens, standard test method was followed according to ASTM E384 standard. In order to measure the hardness, the specimens were cut along the transverse direction. Then the specimens were prepared for cold mounting. Vickers hardness (HV) was measured under test load of 300 gf $(2.94 \mathrm{~N})$ along the longitudinal axis of the test specimen. For each sample, 10 measurements were taken with an interval of $1 \mathrm{~mm}$ to avoid any effect by the neighbouring indentations, and the average value of these hardness measurements was taken into consideration.

\section{RESULTS AND DISCUSSION}

The influence of the weight percentage of aluminium oxide reinforcement on the density of aluminium-aluminium oxide composite specimens before and after the sintering process is shown in Figure 1. These specimens were prepared under 20 ton compaction load and at sintering temperature $550^{\circ} \mathrm{C}$. The measured densities are shown for $5 \%, 10 \%$ and $15 \%$ weight fractions of aluminium oxide in the composites. Before the sintering process, aluminium-aluminium oxide composites containing 5, 10 and 15 weight\% of $\mathrm{Al}_{2} \mathrm{O}_{3}$ particulates exhibited densities $2.5,2.52$ and $2.55 \mathrm{~g} / \mathrm{cm}^{3}$ respectively. On the other hand, after sintering process, aluminium-aluminium oxide composites containing 5,10 and 15 weight $\%$ of $\mathrm{Al}_{2} \mathrm{O}_{3}$ particulates exhibited densities $2.54,2.55$ and $2.6 \mathrm{~g} / \mathrm{cm}^{3}$ respectively. From these obtained results, it is very clear that the density of the composite increases with the increased $\mathrm{Al}_{2} \mathrm{O}_{3}$ particulate weight fraction, After the sintering process, the density of the composites increases $1.6,1.19$ and $1.96 \%$ due to the content of aluminium oxide particulate weight fraction 5,10 and $15 \%$ respectively.

Figure 2 also shows the densities of aluminium-aluminium oxide composites of different percentage compositions before and after the sintering. In this case, all the specimens were prepared under 20 ton compaction load and at sintering temperature $580^{\circ} \mathrm{C}$. The obtained results show that before the sintering process, the measured densities of the composites containing 5, 10 and 15 weight\% of $\mathrm{Al}_{2} \mathrm{O}_{3}$ particulates are $2.47,2.52$ and $2.55 \mathrm{~g} / \mathrm{cm}^{3}$ respectively. On the other hand, after the sintering process, the measured densities of the composites are 2.59, 2.66 and 2.69 $\mathrm{g} / \mathrm{cm}^{3}$ for the 5,10 and 15 weight $\%$ of $\mathrm{Al}_{2} \mathrm{O}_{3}$ particulate contents respectively. The effect of $\mathrm{Al}_{2} \mathrm{O}_{3}$ particulate weight fraction on the density variation of the composite was studied and the density increases $4.86,5.55$ and $5.49 \%$ for the 5,10 and 15 weight $\%$ of $\mathrm{Al}_{2} \mathrm{O}_{3}$ respectively. It can be understood that in general, the densities of the composites 
are higher for $580^{\circ} \mathrm{C}$ sintering temperature than the densities obtained for $550^{\circ} \mathrm{C}$ sintering temperature. Furthermore, as a comparison of these results with the results obtained for $550^{\circ} \mathrm{C}$ sintering temperature (Figure 1), it is certainly clear that in this case (Figure 2), the percentage increase in the density of the composites is somewhat more than that of the sintered $\mathrm{Al}-\mathrm{Al}_{2} \mathrm{O}_{3}$ composites prepared at $550^{\circ} \mathrm{C}$ and containing three different weight fractions of $\mathrm{Al}_{2} \mathrm{O}_{3}$.

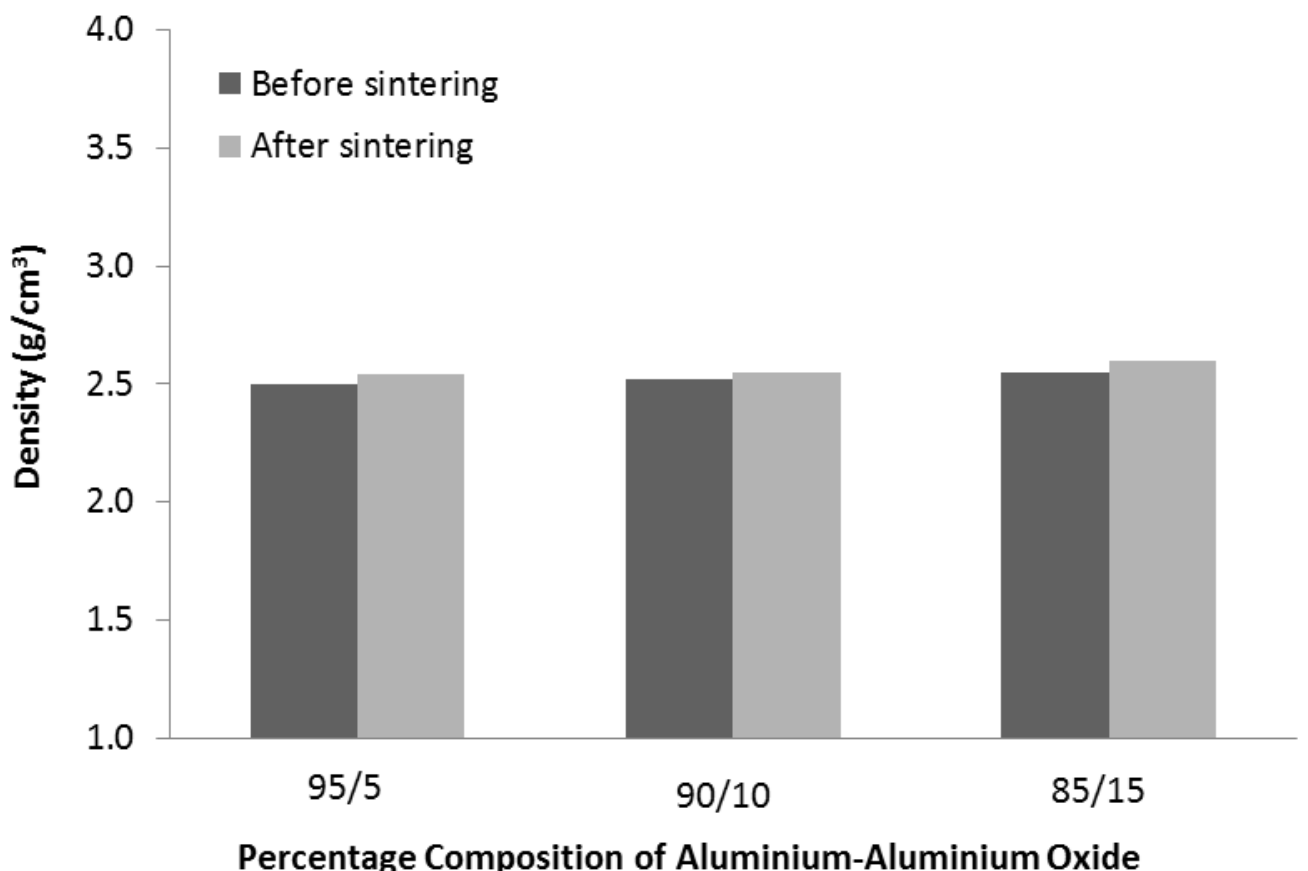

Figure 1: Density variations for different percentage compositions of aluminium-aluminium oxide composites before and after sintering (Sintering temperature: $550^{\circ} \mathrm{C}$ )

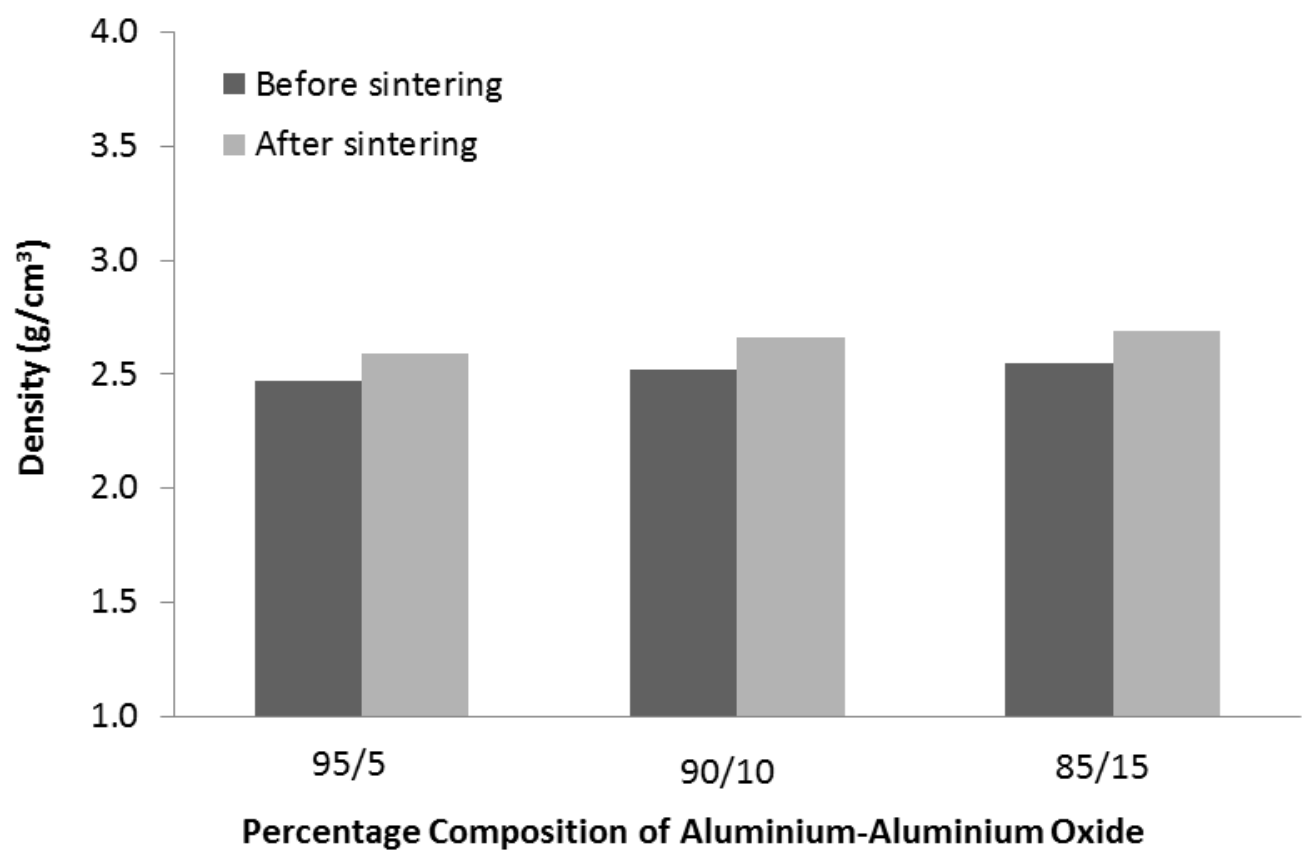

Figure 2: Density variations for different percentage compositions of aluminium-aluminium oxide composites before and after sintering (Sintering temperature: $580^{\circ} \mathrm{C}$ ) 
Variations in hardness of aluminium-aluminium oxide composites containing 5, 10 and 15\% weight fractions of aluminium oxide are shown in Figure 3. These composites were prepared under 20 ton compaction load and at sintering temperature $550^{\circ} \mathrm{C}$. Microvickers hardness testing was carried out under a test load of 300 gf ( $\left.2.94 \mathrm{~N}\right)$ for these $\mathrm{Al}-\mathrm{Al}_{2} \mathrm{O}_{3}$ composite specimens. All these hardness measurements were made along the depth of the specimen and the measured average values of vickers hardness of the composites are 22.6, 23.5 and $24.8 \mathrm{HV}$, containing 5 , 10 and 15 weight\% of $\mathrm{Al}_{2} \mathrm{O}_{3}$ particulates respectively. It is apparent that due to the increase in the weight fraction of $\mathrm{Al}_{2} \mathrm{O}_{3}$ reinforcement, an increase in the hardness of $\mathrm{Al}_{-} \mathrm{Al}_{2} \mathrm{O}_{3}$ composites occurred. The obtained results reveal that the increase in average hardness of the composite is about 3.9\% and $9.7 \%$ for $5 \%$ and $10 \%$ increase in the $\mathrm{Al}_{2} \mathrm{O}_{3}$ weight fraction respectively.

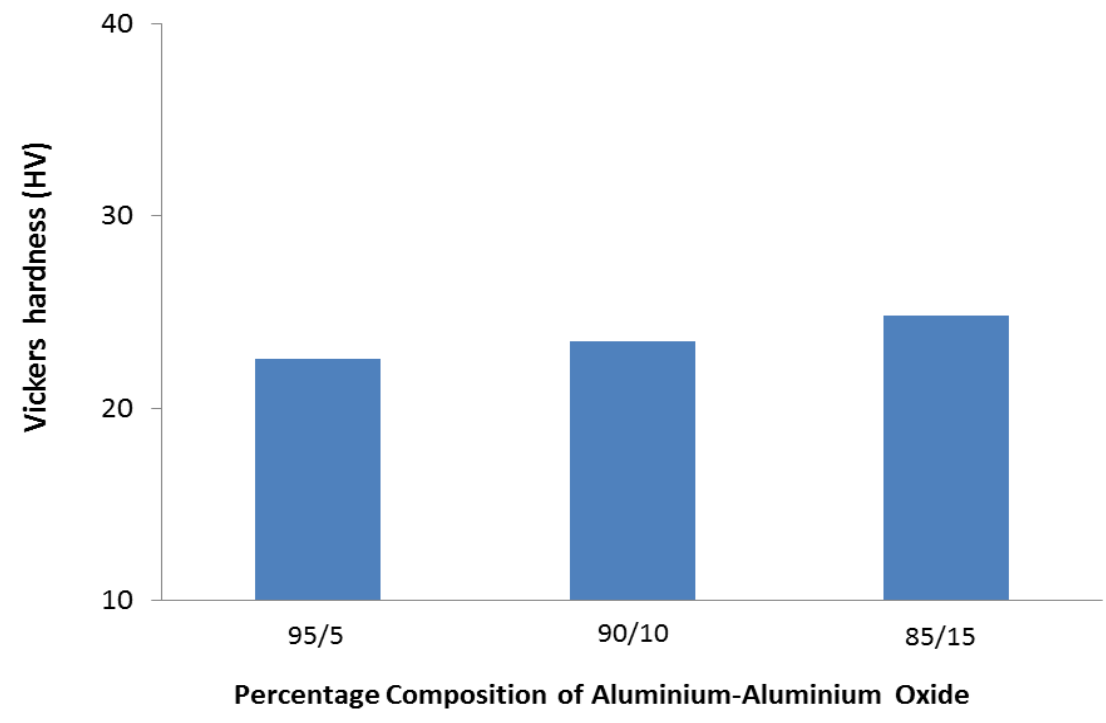

Figure 3: Hardness variations for different percentage compositions of aluminium-aluminium oxide composites (Sintering temperature: $550^{\circ} \mathrm{C}$ ).

Variations in hardness of aluminium-aluminium oxide composites are also shown in Figure 4. In this case, the composites were processed at sintering temperature $580^{\circ} \mathrm{C}$. The measured average values of vickers hardness of the composites are 24.2, 25.5 and $26.7 \mathrm{HV}$ for the 5, 10 and 15 weight $\%$ of $\mathrm{Al}_{2} \mathrm{O}_{3}$ particulates respectively. The average hardness increased by $5.8 \%$ and $10.3 \%$ due to the increase in $5 \%$ and $10 \% \mathrm{Al}_{2} \mathrm{O}_{3}$ weight fraction respectively. It is believed that due to high hardness of $\mathrm{Al}_{2} \mathrm{O}_{3}$ and stronger interfacial bonding between $\mathrm{Al}$ matrix and $\mathrm{Al}_{2} \mathrm{O}_{3}$ particulates at higher sintering temperature, the improvement in the hardness of the $\mathrm{Al}_{-} \mathrm{Al}_{2} \mathrm{O}_{3}$ composites occurred. Moreover, as a comparison of these hardness results with the results obtained for sintering temperature $550^{\circ} \mathrm{C}$ (Figure 3 ), it is indeed clear that in this case (Figure 4), due to the higher sintering temperature, the average hardness of $\mathrm{Al}_{-}-\mathrm{Al}_{2} \mathrm{O}_{3}$ composites of all the compositions is somewhat higher than that of the composites prepared at sintering temperature $550^{\circ} \mathrm{C}$.

Figures 5(a)-(c) show the optical microscopy of $\mathrm{Al}_{-} \mathrm{Al}_{2} \mathrm{O}_{3}$ composites of different compositions prepared at $550^{\circ} \mathrm{C}$ sintering temperature. In the photomicrographs, the blackish part is the $\mathrm{Al}_{2} \mathrm{O}_{3}$ particulates while the whitish part is the aluminium matrix. The micrograph shows reasonably good distribution of $\mathrm{Al}_{2} \mathrm{O}_{3}$ particulates in the aluminium matrix. It is believed that during the fabrication process, good interfacial bonding was achieved between $\mathrm{Al}$ matrix and $\mathrm{Al}_{2} \mathrm{O}_{3}$ particulates. From the figures, it is apparent that the sharpness of the microstructure is good. Figures 6(a)(c) show the microstructure of $\mathrm{Al}-\mathrm{Al}_{2} \mathrm{O}_{3}$ composites of different compositions prepared at $580^{\circ} \mathrm{C}$ sintering temperature. In the micrograph, the whitish part is the aluminium matrix and the blackish part is the $\mathrm{Al}_{2} \mathrm{O}_{3}$ particulates. These micrographs indicate nearly uniform distribution of the $\mathrm{Al}_{2} \mathrm{O}_{3}$ particulates in the aluminium matrix. Moreover, it is apparent that the sharpness of the microstructure is quite strong. It is strongly believed that strong particle-matrix interfacial bonding was achieved during processing of the samples at higher sintering temperature. These results are supported by the measured hardness in Figure 4. As a comparison, these $\mathrm{Al}_{-} \mathrm{Al}_{2} \mathrm{O}_{3}$ composites prepared at $580^{\circ} \mathrm{C}$ show somewhat improved microstructure than the composites prepared at $550^{\circ} \mathrm{C}$ (Figure 5). 


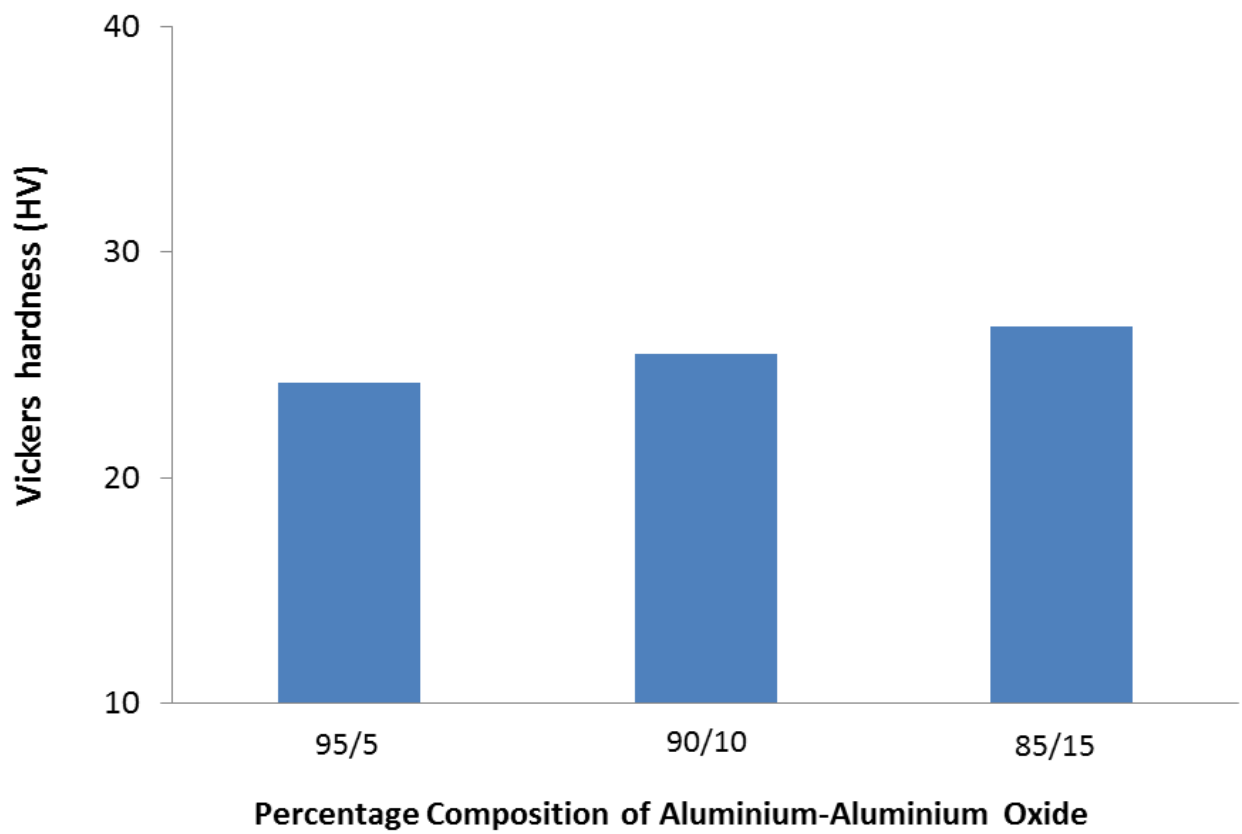

Figure 4: Hardness variations for different percentage compositions of aluminium-aluminium oxide composites (Sintering temperature: $580^{\circ} \mathrm{C}$ )

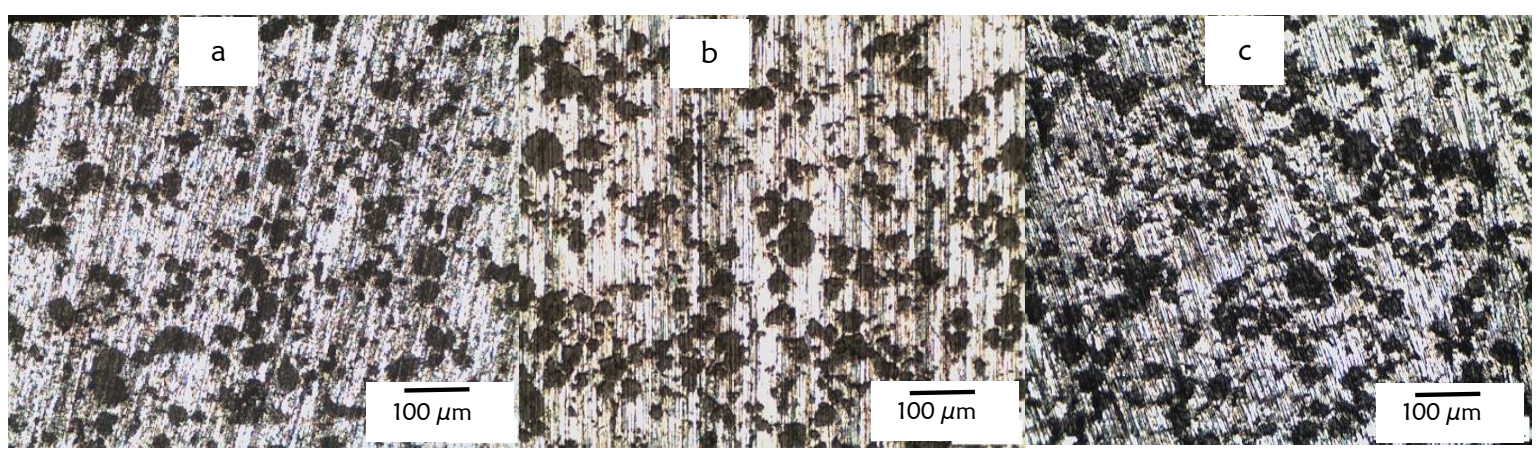

Figure 5: Microstructure at $550^{\circ} \mathrm{C}$ (a) $95 \% \mathrm{Al}+5 \% \mathrm{Al}_{2} \mathrm{O}_{3}$ (b) $90 \% \mathrm{Al}+10 \% \mathrm{Al}_{2} \mathrm{O}_{3}$ (c) $85 \% \mathrm{Al}+15 \% \mathrm{Al}_{2} \mathrm{O}_{3}$

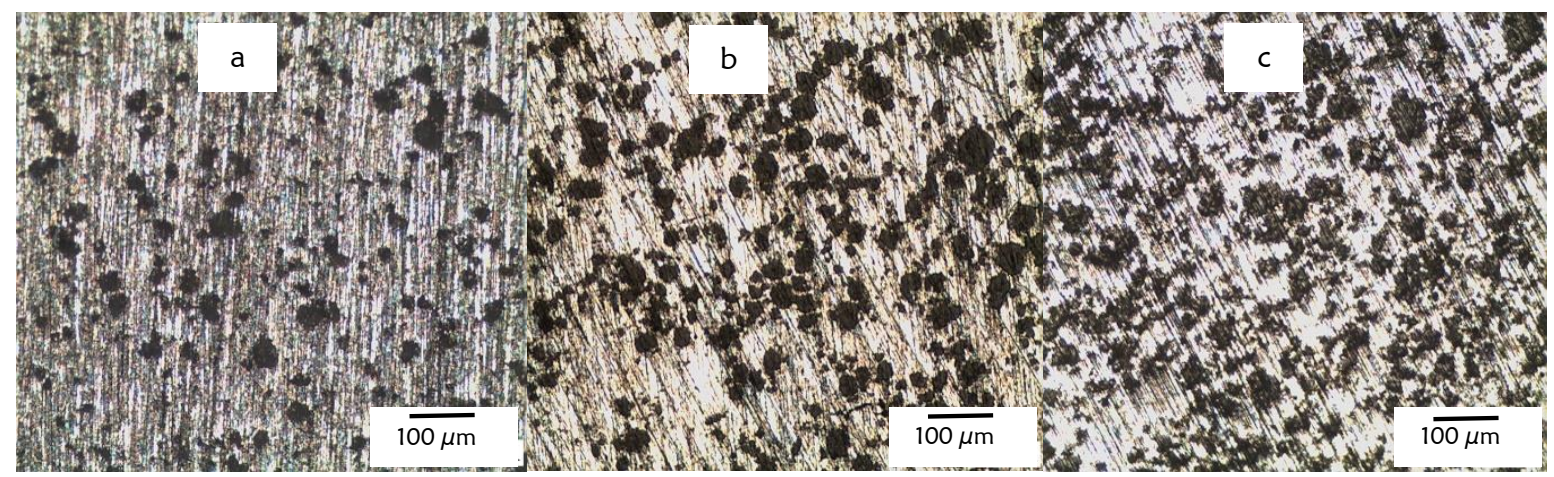

Figure 6: Microstructure at $580^{\circ} \mathrm{C}$ (a) $95 \% \mathrm{Al}+5 \% \mathrm{Al}_{2} \mathrm{O}_{3}$ (b) $90 \% \mathrm{Al}+10 \% \mathrm{Al}_{2} \mathrm{O}_{3}$ (c) $85 \% \mathrm{Al}+15 \% \mathrm{Al}_{2} \mathrm{O}_{3}$ 


\section{CONCLUSION}

In this study, the effects of sintering temperature and weight fraction of $\mathrm{Al}_{2} \mathrm{O}_{3}$ particulates on the properties of $\mathrm{Al}$ $\mathrm{Al}_{2} \mathrm{O}_{3}$ composites were investigated. It was observed that density of composite specimen increases with the increase in $\mathrm{Al}_{2} \mathrm{O}_{3}$ weight percentage in $\mathrm{Al}-\mathrm{Al}_{2} \mathrm{O}_{3}$ composite. Hardness of the composite specimen also increases with the increase in $\mathrm{Al}_{2} \mathrm{O}_{3}$ percentage in $\mathrm{Al}-\mathrm{Al}_{2} \mathrm{O}_{3}$ composite. Moreover, it was observed that density, hardness and microstructure of the composites were significantly influenced by the sintering temperature. $\mathrm{Al}_{-} \mathrm{Al}_{2} \mathrm{O}_{3}$ composites showed higher density and hardness when these composites were processed at sintering temperature $580^{\circ} \mathrm{C}$ as compared to the composites that were processed at $550^{\circ} \mathrm{C}$. Due to the improved particle-matrix interfacial bonding at higher sintering temperature, the composite showed better properties. As a result, the composites showed improved microstructure at $580^{\circ} \mathrm{C}$ as compared to the composites that were processed at $550^{\circ} \mathrm{C}$.

\section{ACKNOWLEDGEMENTS}

The authors wish to thank University Malaysia Pahang for the financial support through research grant RDU130350. The authors also wish to extend their sincere thanks to all the technical staffs involved to complete this research work.

\section{REFERENCES}

1. Lees, J. K., Dhihra, A. K., \& McCullough R. L. (2005) Composite Materials, Wiley.

2. Chawla, K. K. (2013) Composite Materials: Science and Engineering - Springer.

3. Veeresh, K. G. B., Rao, C. S. P., \& Selvaraj, N. (2011). Mechanical and tribological behavior of particulate reinforced aluminum metal matrix composites - A review. Journal of Minerals \& Materials Characterization \& Engineering, 10(1), 59-91.

4. Mahendra, B. M., Arulshri K. P., \& lyandurai, N. (2013). Evaluation of mechanical properties of aluminium alloy 2024 reinforced with silicon carbide and fly ash hybrid metal matrix composites. American Journal of Applied Sciences, 10(3), 219-229.

5. Daoud, A., \& Abou El-khair, M. T. (2009). Wear and friction behavior of sand cast brake rotor made of A359$20 \mathrm{vol} \% \mathrm{SiC}$ particle composites sliding against automobile friction material. Tribology International, 43(3), 544-553.

6. Arivukkarasan, S., Dhanalakshmi, V., Suresh Babu, A., \& Aruna, M. (2013). Performance study on fatigue behaviour in aluminium alloy and alumina silicate particulate composites. Journal of Applied Science \& Engineering, 16(2), 127-134.

7. Fang, C. K., Fang, R. L., Weng, W. P., \& Chuang, T. H. (1999). Applicability of ultrasonic testing for the determination of volume fraction of particulates in alumina-reinforced aluminum matrix composites. Materials Characterization, 43(4), 217-226.

8. Tatar, C., \& Ozdemir, N. (2010). Investigation of thermal conductivity and microstructure of the $\alpha-\mathrm{Al}_{2} \mathrm{O}_{3}$ particulate reinforced aluminium composites $\left(\mathrm{Al} / \mathrm{Al}_{2} \mathrm{O}_{3}-\mathrm{MMC}\right)$ by powder metallurgy method. Physica $\mathrm{B}$ : Condensed Matter, 405(3), 896-899.

9. Dasgupta, R., \& Meenai, H. (2005). SiC particulate dispersed composites of an Al-Zn-Mg-Cu alloy: Property comparison with parent alloy. Materials Characterization, 54(4-5), 438-445.

10. Guo, Z., Xiong, J., Yang, M., \& Li, W. (2008). Microstructure and properties of tetrapod-like ZnO whiskers reinforced al matrix composite. Journal of Alloy and Compounds, 461(1-2), 342-345.

11. Singla, M., Dwivedi, D. D., Singh, L., \& Chawla, V. (2009). Development of aluminium based silicon carbide particulate metal matrix composite. Journal of Minerals \& Materials Characterization \& Engineering, 8(6), 455467. 